\title{
Mulches and Biosolids Affect Vigor, Yield and Leaf Nutrition of Fertigated High Density Apple
}

\author{
G.H. Neilsen, E.J. Hogue, T. Forge, and D. Neilsen \\ Agriculture and Agri-Food Canada, Pacific Agri-Food Research Centre, \\ Summerland, B.C., VOH 1Z0, Canada
}

Additional index words. Malus $\times$ domestica, drip-fertigation, ground cover, soil management

\begin{abstract}
Spartan' apple (Malus $\times$ domestica Borkh.) trees on M.9 (T337) rootstock were planted in April 1994 at $1.25 \mathrm{~m} \times 3.5 \mathrm{~m}$ spacing. Seven soil management treatments were applied within a 2-m-wide strip centered on the tree row and arranged in a randomized complete-block experimental design. Treatments included a weed-free strip (check) maintained with four annual applications of glyphosate; surface application of $45 \mathrm{t} \cdot \mathrm{ha}^{-1}$ of Greater Vancouver Regional District (GVRD) biosolids applied in 1994 and again in 1997; mulches of shredded office paper; alfalfa (Medicago sativa L.) hay; black woven polypropylene; and shredded paper applied over $45 \mathrm{t} \cdot \mathrm{ha}^{-1} \mathrm{GVRD}$-and Kelowna-biosolids applied in 1994 and 1997. All experimental trees were fertigated with phosphorus $(P)$ in the first year and with nitrogen (N) annually. Cumulative yield for the first five harvests was higher for trees subjected to any soil management treatment relative to check trees. Maximum cumulative yield, exceeding check trees by $80 \%$, was measured for trees grown with a shredded paper mulch with or without biosolids application. Trees from the three shredded paper treatments were the only ones significantly larger than check trees after six growing seasons. No increases in leaf nutrient concentration were consistently associated with improved tree performance. Notable effects included increased leaf $P$ concentration associated with biosolids application, increased leaf $K$ concentration after alfalfa mulch application and temporary increases in leaf $\mathrm{Zn}$ and $\mathrm{Cu}$ concentration associated with application of biosolids high in $\mathrm{Zn}$ and $\mathrm{Cu}$. Use of both mulches and biosolids amendments benefits growth of trees in high density plantings despite daily drip irrigation and annual fertigation.
\end{abstract}

Recent interest in minimizing use of agrochemicals in fruit growing to safeguard environmental and human health has stimulated interest in integrated fruit production (IFP). Components of such production systems have been discussed in several recent international conferences (International Society for Horticultural Science, 1990,1996). Although several options for nonchemical control of insects and diseases exist, including disease-resistant cultivars and alternatives to soil fumigation, the alternatives for weed control in high density apple (Malus $\times$ domestica Borkh.) orchards often have not maintained satisfactory production (Schink and Wertheim, 1992).

Mulching is a traditional weed control method that offers important potential benefits by maintaining a high quality soil environment (Hogue and Neilsen, 1987). As sources of available mulches have diversified, a revival of interest in this method has recently been documented (Merwin et al., 1995). Several recent field trials in humid regions have identified beneficial effects of mulching on apple tree performance (Merwin and Stiles, 1994), soil moisture content (Merwin et al., 1994) and biological activity in orchard soils (Hartley et al., 1996). Little information is available concerning the effects of mulching in high

Received for publication 20 Nov. 2001. Accepted for publication 8 May 2002. Pacific Agri-Food Research Centre contribution 2144. density apple orchards in irrigated regions where daily irrigation and fertigation might be expected to reduce potential nutrient and water stresses. Of particular interest would be the effect of mulching on several problems associated with fertigation of coarse-textured soils, including acidification (Neilsen et al., 1999) and the development of K-deficiency (Neilsen et al., 2000). Also of interest would be the effect of using mulches in association with organic waste amendments. Biosolids and other biowaste amendments have improved the growth of annual horticultural crops in sandy soils, but their effects in perennial cropping systems have received little attention (Neilsen et al., 1998).

Thus, a long-term field trial was established to study the effects of various mulch and organic waste combinations on growth, yield and nutrition of drip-fertigated apple trees. The effects of these treatments on microbiological activity in these soils has been described elsewhere (Forge et al., 2003).

\section{Materials and Methods}

An experimental block of 'Spartan' apple trees on M.9 (T337) rootstock was planted at the Pacific Agri-Food Research Centre at Summerland in Apr. 1994 at $1.25 \times 3.5-\mathrm{m}$ spacing. Trees were trained as slender spindles, each tree supported by a post. Commencing the year of planting, seven soil management treatments were established in a 2.0 -m-wide strip centered on the tree rows. Treatments were applied in a randomized complete-block design with four measurement trees per treatment, replicated in five blocks. 'Royal Gala' pollinizer trees separated all four-tree treatment plots. Treatments included:

1) Check. Plots were maintained weed-free year-round via applications of glyphosate (N-[phosphonomethyl] glycine) at 1.0 $\mathrm{kg} \cdot \mathrm{ha}^{-1}$ a.i., annually, usually in early May, mid-June, late August, and late October.

2) Greater Vancouver Regional District (GVRD)-biosolids. This plot was maintained in the same manner (including herbicide application) as the check plot, but had $45 \mathrm{t} \cdot \mathrm{ha}^{-1}$ (oven dry) of minimally composted sewage sludge from GVRD applied to the soil surface in July 1994 and again in June 1997.

Mulches included:

3) Shredded office paper, which was initially applied uniformly to cover the weed-free soil surface at $15 \mathrm{~kg} / \mathrm{plot}(2 \mathrm{~m} \times 6.25 \mathrm{~m})$ in July, 1994 and annually at $5 \mathrm{~kg} /$ plot to maintain complete cover.

4) Alfalfa straw, which was applied first in mid-May, 1994 at a rate of $\approx 30 \mathrm{~kg} / \mathrm{plot}$ and annually at $15 \mathrm{~kg} / \mathrm{plot}$ to maintain complete cover.

5) Black woven polypropylene. This fabric (Sarlonshade Corp. of America, Miami), permeable to irrigation water, was installed 15 Apr. 1994 with edges buried in the soil.

Shredded paper mulch was applied and maintained as described previously over:

6) $45 \mathrm{t} \cdot \mathrm{ha}^{-1}$ of Kelowna-biosolids; and

7) 45 th ha ${ }^{-1}$ of GVRD-biosolids, both applied initially in July 1994.

The paper mulch only was lifted and reapplied after a second application of the respective biosolids at $45 \mathrm{t} \cdot \mathrm{ha}^{-1}$ in June 1997 . The nutrient content of Kelowna, GVRD- biosolids and paper and alfalfa mulches is summarized in Table 1. After the first year, all mulched plots were spot-treated with glyphosate every spring, if required, to control weeds that emerged through thinned areas or holes in the mulches or at the plot boundaries. This was not generally necessary for the black plastic except for slits near the trees or supporting posts. As a result, there were few differences in weed growth among treatments. The narrow $(1.5 \mathrm{~m})$ inter-row zone was sown to a grass sod. Vigor of this stand was low due to drip-irrigation within the tree rows. When mown, clippings essentially fell where cut.

The experimental site was located on a Skaha gravelly sandy loam, an Orthic Brown Chernozemic (Aridic Ustochrept) soil developed on fluvial glacial deposits and commonly planted to tree fruits and vineyards in the south Okanagan (Wittneben, 1986). These soils are typically coarse-textured, low in organic matter, rapidly drained and low in water holding capacity like many of the orchard soils in the semi-arid regions of British Columbia and Washington State. Insects and diseases were 
Table 1. Average nutrient content of applied biosolids and mulches.

\begin{tabular}{lccccccc}
\hline & \multicolumn{7}{c}{ Total nutrient concn } \\
\cline { 2 - 7 } Material & $\mathrm{N}$ & $\mathrm{P}$ & $\mathrm{K}$ & $\mathrm{Ca}$ & $\mathrm{Mg}$ & $\mathrm{Zn}$ & $\mathrm{Cu}$ \\
\hline \multirow{2}{*}{ GVRD-biosolids } & --- & --- & $\mathrm{g} \cdot \mathrm{kg}^{-1} \mathrm{dw}^{\mathrm{z}}$ & --- & --- & $-\mathrm{mg} \cdot \mathrm{kg}^{-1} \mathrm{dw}_{-}^{-}$ \\
Kelowna-biosolids & 33.0 & 11.0 & 5.0 & 24.0 & 2.0 & 758 & 977 \\
Shredded paper mulch & 19.0 & 18.0 & 5.0 & 12.0 & 6.0 & 234 & 393 \\
Alfalfa mulch & 2.4 & 0.03 & 0.2 & 57.0 & 1.0 & 0.1 & 0.07 \\
\hline
\end{tabular}

${ }^{\mathrm{z}}$ Dry weight $=\mathrm{dw}$.

controlled according to standard commercial production practices (British Columbia Ministry of Agriculture and Food, 1998). Irrigation was supplied from May to October to exceed minimum requirements through two $4 \mathrm{~L} \cdot \mathrm{h}^{-1}$ drip emitters located $0.5 \mathrm{~m}$ from each tree trunk within the tree row on both sides of the tree. From 1994 to 1998, irrigation was applied for $2 \mathrm{~h}$ per day until mid-August and after that for $2 \mathrm{~h}$ every second day. In 1999, irrigation was $2 \mathrm{~h}$ every second day until mid-August and $1.5 \mathrm{~h}$ every second day after that. Fertilizers were applied directly through the irrigation system commencing with a total of $10 \mathrm{~g} \mathrm{P}$ (23 $\left.\mathrm{kg} \cdot \mathrm{ha}^{-1} \mathrm{P}\right)$ and $30 \mathrm{~g} \mathrm{~N}\left(70 \mathrm{~kg} \cdot \mathrm{ha}^{-1} \mathrm{~N}\right)$ per tree as a combination of ammonium polyphosphate $(10 \mathrm{~N}-15 \mathrm{P}-0 \mathrm{~K})$ and ammonium nitrate (34N-0P-0K). From 1995 to 1999 , N only was fertigated as ammonium nitrate $(34 \mathrm{~N}-0 \mathrm{P}-0 \mathrm{~K})$ for a 6-week period commencing immediately postbloom for a total of $30 \mathrm{~g} \mathrm{~N}$ per tree per year except for $1996\left(35 \mathrm{~g} \mathrm{~N}, 80 \mathrm{~kg} \cdot \mathrm{ha}^{-1} \mathrm{~N}\right)$ and 1998 (45 g N, $\left.100 \mathrm{~kg} \cdot \mathrm{ha}^{-1} \mathrm{~N}\right)$.

Trunk diameter at $0.3 \mathrm{~m}$ above the graft union was measured each spring (late Aprilearly May) commencing in the year of planting (1994) until 1998 for all treatment trees. A final diameter measurement was made in Nov. 1999. A 30-leaf sample for each experimental unit was collected in mid-July, 1994-99, from the midportion of extension shoots of the current year's growth. All samples were oven-dried at $65^{\circ} \mathrm{C}$ and ground in a stainless steel Wiley mill (A.H. Thomas Co., Philadelphia). A 250mg subsample was digested for $0.75 \mathrm{~h}$ on a block digester at $350{ }^{\circ} \mathrm{C}$ in a $\mathrm{H}_{2} \mathrm{SO}_{4}$ solution containing $\mathrm{K}_{2} \mathrm{SO}_{4}$ and $\mathrm{HgO}$. Nitrogen in the digest was determined through the formation of an ammonium-salicylate complex and $\mathrm{P}$ was determined through the formation of a phosphomolybdenum blue complex (Technicon Autoanalyzer II Industrial Method No. 334-74A/A; Technicon, Elmsford, N.Y.). Onegram samples were also dry-ashed at $475^{\circ} \mathrm{C}$ and dissolved in $0.5 \mathrm{~m} \mathrm{HCI}$ for determination of $\mathrm{Ca}, \mathrm{Mg}, \mathrm{K}, \mathrm{Mn}, \mathrm{Zn}, \mathrm{Fe}$, and $\mathrm{Cu}$ by atomic absorption spectrophotometry. Annual yield was measured for each treatment and replicate at harvest from 1995 to 1999 and expressed on a per tree basis. Cumulative yield efficiency was calculated as cumulative yield from 1995 to 1999 divided by trunk cross-sectional area (TCA) as measured in Nov. 1999. The number of harvested fruit was recorded for each plot allowing the calculation of average fruit size.

Analysis of variance (ANOVA) was performed on leaf nutrient, growth and yield data as a randomized complete-block design with seven soil management treatments, replicated five times. Data were analyzed separately by year, since trees changed from being vegetative to having an increasing crop load over time. All statistical analyses were undertaken using the general linear model (GLM) procedure (SAS Institute, 1989). Treatment means were separated using Duncan's multiple range test at the level of probability indicated.

\section{Results and Discussion}

Vigor and yield. Average TCA was affected by soil management treatment the year after planting (1995, Table 2). After six growing seasons, the largest trees were associated with the shredded paper mulch treatment with TCA being more than $50 \%$ larger than check trees $(P$ $\leq 0.0001)$. Application of $45 \mathrm{t} \cdot \mathrm{ha}^{-1}$ of GVRD-or Kelowna-biosolids once every 3 years beneath the paper mulch did not further increase TCA. Trees grown under black plastic mulch were larger than check trees from Spring 1995 until Spring 1997, but thereafter were the same size. Similarly trees grown under an alfalfa straw mulch were no larger than check trees after 6 years despite being larger until Spring 1998. Smallest trees were consistently observed for the check treatment and for trees grown with $45 \mathrm{t} \cdot \mathrm{ha}^{-1}$ of GVRD-biosolids, applied once every 3 years.

The improvement in tree vigor observed for mulched trees in our study has been a generally reported consequence of mulching fruit trees (Haynes, 1980). Improvements in shorter term tree vigor have previously been attributed to improved soil quality (Cockcroft and Tisdall, 1974), increased availability of nitrogen (Boynton and Anderson, 1956) or of water (Shribbs and Skroch, 1986). In the longer term, only mulches containing shredded paper resulted in significantly larger trees than those grown in a herbicide strip (check treatment), implying that in the long term alfalfa straw and black plastic mulch had similar effects on tree growth as the standard herbicide treatment.

Soil management treatments also significantly affected fruit yield in three of the five fruiting seasons (Table 3 ). In these years, yields exceeding those measured for check trees were observed for various treatments that involved mulch application to the soil surface, including alfalfa (1 year), black plastic or shredded paper applied alone or with GVRD-biosolids (all 3 years). Cumulative 5-year yields were higher $(P<0.001)$ for all six soil management treatments relative to the check treatment. Cumulative yield of trees to which GVRD-biosolids had been applied in 1994 and 1997 exceeded yield of check trees by $19 \%$ despite there being no significant differences in yield in any single year. Maximum cumulative yield ( $80 \%$ above check treatment) was measured for trees grown under shredded paper mulch. Cumulative yield for this treatment however did not exceed cumulative yield for the other mulch treatments, excepting the alfalfa straw mulch. In general, higher cumulative yield was associated with larger trees. However the cumulative yield efficiency of trees treated with GVRD-biosolids or black plastic mulch was higher than check trees (Table 3 ). These trees yielded more fruit than expected considering that their TCA was similar to check trees. Fruit size was significantly $(P \leq 0.05$ or 0.01$)$ affected by soil management treatment every other year, commencing the first year of fruiting in 1995 (Table 3). The most consistent effect in these years was large fruit size measured on trees mulched with alfalfa.

Inconsistent effects of mulching on yield have previously been reported. For example, both increased yield (Baxter, 1970) or no significant yield differences have been reported between (straw) mulch treatment relative to herbicide strips (Merwin and Stiles, 1994). However, over a 6-year period, the lowest cumulative yields were measured in our study for trees maintained in herbicide strips with yields higher for all other soil management treatments, including one where 45 $\mathrm{t} \cdot \mathrm{ha}^{-1}$ of GVRD-biosolids were applied to the soil surface every third year and which never showed an annual yield greater than the herbicide check. Thus, all mulches increased yield for high density dwarf apple trees grown on coarse-textured soils in semi-arid regions despite an apparently optimum nutrient and water regime provided by daily drip irrigation and annual fertigation.

Major leaf nutrients. Soil management treatment did not have a consistent effect on leaf N concentration, with significant differences $(P$ $\leq 0.05$ or 0.01 ) observed among treatments in only three of six years (Table 4). In the first year,

Table 2. Annual trunk cross-sectional area at 0.3 m height, 1994-99, of 'Spartan' apple on M.9 rootstock, as affected by soil management treatment.

\begin{tabular}{lcccccc}
\hline & \multicolumn{5}{c}{ Avg trunk cross-sectional area $\left(\mathrm{cm}^{2}\right)$} \\
\cline { 2 - 7 } Treatment & Spring & Spring & Spring & Spring & Spring & Fall \\
Check (herbicide strip) & 1994 & 1995 & 1996 & 1997 & 1998 & 1999 \\
GVRD-biosolids & 0.9 & $1.4 \mathrm{c}$ & $1.9 \mathrm{~d}$ & $3.1 \mathrm{c}$ & $4.6 \mathrm{c}$ & $8.2 \mathrm{c}$ \\
Shredded paper mulch & 0.9 & $1.5 \mathrm{bc}$ & $2.2 \mathrm{~cd}$ & $3.2 \mathrm{c}$ & $4.5 \mathrm{c}$ & $8.3 \mathrm{c}$ \\
Alfalfa mulch & 1.0 & $1.8 \mathrm{a}$ & $3.3 \mathrm{ab}$ & $5.0 \mathrm{a}$ & $7.4 \mathrm{a}$ & $12.4 \mathrm{a}$ \\
Shredded paper \& Kelowna biosolids & 1.0 & $1.5 \mathrm{bc}$ & $2.7 \mathrm{bc}$ & $4.0 \mathrm{bc}$ & $6.1 \mathrm{ab}$ & $10.0 \mathrm{bc}$ \\
Black plastic mulch & 1.0 & $1.7 \mathrm{ab}$ & $3.1 \mathrm{ab}$ & $4.5 \mathrm{ab}$ & $6.4 \mathrm{ab}$ & $11.4 \mathrm{ab}$ \\
Shredded paper \& GVRD biosolids & 0.9 & $1.7 \mathrm{ab}$ & $2.9 \mathrm{~b}$ & $4.2 \mathrm{ab}$ & $5.8 \mathrm{bc}$ & $9.3 \mathrm{c}$ \\
Treatment significance & 1.1 & $1.8 \mathrm{a}$ & $3.6 \mathrm{a}$ & $5.1 \mathrm{a}$ & $7.3 \mathrm{ab}$ & $12.2 \mathrm{a}$ \\
& NS & $* *$ & $* * * *$ & $* * *$ & $* * *$ & $* * * *$ \\
\hline
\end{tabular}

Ns, **,***,*****Nonsignificant or significant at $P \leq 0.01,0.001$, or 0.0001 , respectively. 
Table 3. Annual and cumulative harvest yield, cumulative yield efficiency, and average fruit size, 1995-99, of 'Spartan' on M.9 rootstock, as affected by soil management treatment.

\begin{tabular}{|c|c|c|c|c|c|c|c|c|c|c|c|c|}
\hline \multirow[b]{2}{*}{ Treatment } & \multicolumn{12}{|c|}{$\begin{array}{c}\text { Cumulative yield } \\
\text { efficiency }\end{array}$} \\
\hline & 1995 & 1996 & 1997 & 1998 & 1999 & 1995-99 & $\left(\mathrm{kg} \cdot \mathrm{cm}^{-2}\right)$ & 1995 & 1996 & 1997 & 1998 & 1999 \\
\hline Check (herbicide strip) & 0.5 & $1.4 \mathrm{c}$ & $3.2 \mathrm{c}$ & $4.6 \mathrm{c}$ & 3.2 & $12.9 \mathrm{c}$ & $1.62 \mathrm{~b}$ & $207 \mathrm{c}$ & 164 & $174 \mathrm{bc}$ & 183 & $187 \mathrm{bc}$ \\
\hline GVRD biosolids & 0.8 & $2.1 \mathrm{bc}$ & $4.5 \mathrm{bc}$ & $5.2 \mathrm{bc}$ & 4.6 & $16.0 \mathrm{~b}$ & $2.10 \mathrm{a}$ & $212 \mathrm{bc}$ & 147 & $165 \mathrm{e}$ & 184 & $188 \mathrm{bc}$ \\
\hline Shredded paper mulch & 0.6 & $3.3 \mathrm{a}$ & $6.5 \mathrm{a}$ & $7.2 \mathrm{ab}$ & 6.0 & $23.4 \mathrm{a}$ & $1.91 \mathrm{ab}$ & $237 \mathrm{ab}$ & 165 & $170 \mathrm{c}$ & 182 & $184 \mathrm{bc}$ \\
\hline Alfalfa mulch & 0.5 & $2.7 \mathrm{ab}$ & $3.7 \mathrm{bc}$ & $7.0 \mathrm{ab}$ & 3.3 & $17.3 \mathrm{~b}$ & $1.76 \mathrm{~b}$ & $259 \mathrm{a}$ & 159 & $209 \mathrm{a}$ & 191 & 208 a \\
\hline Shredded paper \& Kelowna biosolids & 0.5 & $2.5 \mathrm{ab}$ & $5.3 \mathrm{ab}$ & $6.8 \mathrm{a}-\mathrm{c}$ & 5.6 & $20.7 \mathrm{ab}$ & $1.84 \mathrm{ab}$ & $236 \mathrm{a}-\mathrm{c}$ & 167 & $169 \mathrm{c}$ & 197 & $195 \mathrm{ab}$ \\
\hline Black plastic mulch & 0.5 & $2.9 \mathrm{ab}$ & $5.2 \mathrm{ab}$ & $6.9 \mathrm{a}-\mathrm{c}$ & 4.4 & $20.0 \mathrm{ab}$ & $2.12 \mathrm{a}$ & $253 \mathrm{ab}$ & 172 & $184 \mathrm{bc}$ & 176 & $175 \mathrm{c}$ \\
\hline Shredded paper \& GVRD biosolids & 0.4 & $2.5 \mathrm{ab}$ & $5.4 \mathrm{ab}$ & $7.7 \mathrm{a}$ & 5.0 & $21.2 \mathrm{ab}$ & $1.75 \mathrm{~b}$ & $266 \mathrm{a}$ & 175 & $192 \mathrm{ab}$ & 183 & $188 \mathrm{bc}$ \\
\hline Treatment significance & NS & $* *$ & $* *$ & $*$ & NS & $* * *$ & $*$ & $*$ & NS & $* *$ & NS & $* *$ \\
\hline
\end{tabular}

Ns, ${ }^{*}, * *, * * *$ Nonsignificant or significant at $P \leq 0.05,0.01$, or 0.001 , respectively.

leaf $\mathrm{N}$ concentrations exceeded leaf $\mathrm{N}$ of check trees only for treatments involving shredded paper mulch alone or with GVRD-biosolids applied that same year, while in the second year, leaf $\mathrm{N}$ concentration was maximum for the alfalfa mulch treatment. The only other year significant differences were observed in leaf $\mathrm{N}$ concentration was 1997 when re-application of GVRD-biosolids resulted in leaf N concentrations which exceeded values measured in the shredded paper, alfalfa and shredded paper + GVRD treatments. It is unlikely that any of these changes in $\mathrm{N}$ availability, as indicated by the observed increases in leaf $\mathrm{N}$ concentrations, significantly affected growth or yield of 'Spartan'. Leaf $\mathrm{N}$ values for all treatments were often high (could exceed $27 \mathrm{~g} \cdot \mathrm{kg}^{-1}$ ) and even in 1999, when lowest values were observed, they were in the upper range of the 18 to 25 $\mathrm{g} \cdot \mathrm{kg}^{-1}$ adequacy values for young 'Spartan' apple trees (British Columbia Ministry of Agriculture and Food, 1998). Despite high leaf $\mathrm{N}$ concentrations, there were few obvious effects on fruit quality including color among treatments. 'Spartan' is known to be a highly colored cultivar in this region.

Leaf $\mathrm{P}$ concentrations were more affected by soil management treatment than leaf $\mathrm{N}$, with significant differences $(P \leq 0.05$ to $P \leq$ $0.0001)$ measured in five of the first six growing seasons (Table 4). In each of these years, trees grown in the shredded paper mulch applied over Kelowna biosolids had leaf $\mathrm{P}$ concentrations significantly greater than that of check trees and, with the exception of the first year, had the highest $\mathrm{P}$ concentration of all treatments. Similar increases (3 years) in leaf P concentration relative to check trees were also observed for the shredded paper plus GVRD-biosolids treatment. Alfalfa (2 years), shredded paper (1 year), black plastic (1 year), and amendment via GVRD-biosolids (1 year) also occasionally increased leaf P concentration relative to check trees. Few reports have emphasized the benefits of mulching on apple tree P nutrition (Hogue and Neilsen, 1987). In contrast, biosolids have previously been shown to be effective Psources for irrigated vegetables when rototilled into the surface soil (Neilsen et al., 1998). This research would imply that biosolids can be a source of $\mathrm{P}$ for apples, even when surface-applied, especially when placed beneath a mulch which seems to create conditions suitable for P-uptake. Nevertheless, despite the changes in leaf $\mathrm{P}$ concentration observed in the study, values for all treatments exceeded the 1.5 $\mathrm{g} \cdot \mathrm{kg}^{-1}$ concentration generally considered

Table 4. Average leaf nutrient N, P, K, Mg and Ca concentration of 'Spartan' apple on M.9 rootstock as affected by soil management treatments, 1994-99.

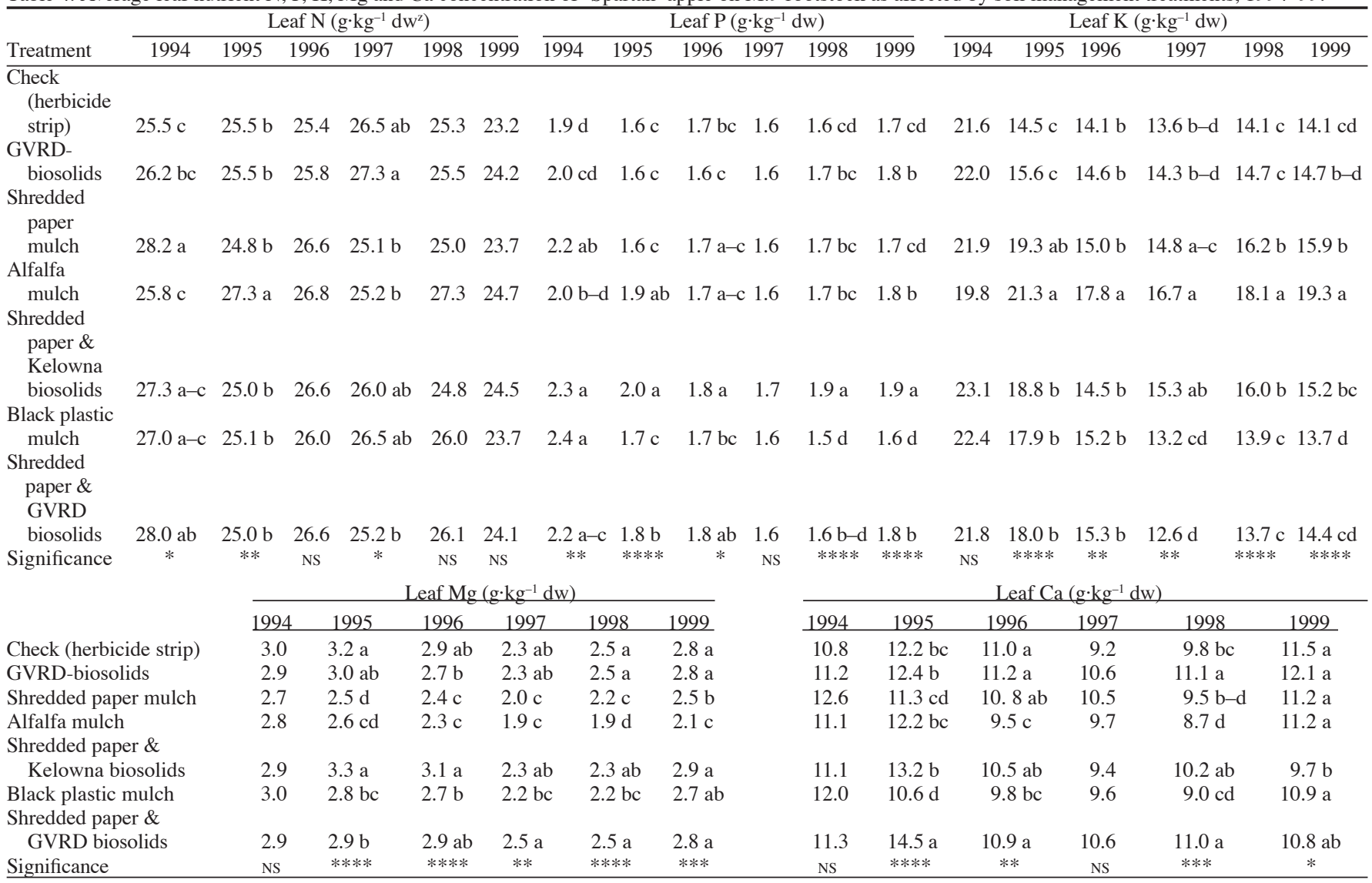

${ }^{\mathrm{z}}$ Dry weight $=\mathrm{dw}$.

Ns, $, * *, * * *, * * * *$ Nonsignificant or significant at $P \leq 0.05,0.01,0.001$, or 0.0001 , respectively. 
adequate for growth of mature apple trees (British Columbia Ministry of Agriculture and Food, 1998).

Leaf K concentration was significantly $(P \leq$ 0.01 to $P \leq 0.0001$ ) affected by treatment in all but the first year of the study (Table 4). The most consistent effect was associated with the alfalfa mulch where trees had the highest leaf K concentrations in the last 5 years of the study. All other mulches increased leaf K concentrations in the year after planting (1995), while shredded paper alone (2 years) or with Kelowna biosolids (1 year) periodically increased leaf K. Mulches which involve the addition of high $\mathrm{K}$ organic materials to the soil surface (eg. alfalfa, Table 1), have long been associated with higher leaf K concentrations (Hogue and Neilsen, 1987). By the end of the study, treatments such as check and black plastic mulch, which eliminate or reduce the recycling of orchard floor vegetation to the soil surface, resulted in trees with leaf K concentrations $<14 \mathrm{~g} \cdot \mathrm{kg}^{-1}$. Such values are close to the critical $12 \mathrm{~g} \cdot \mathrm{kg}^{-1}$ leaf $\mathrm{K}$ threshold likely to affect adversely apple tree growth (Shear and Faust, 1980). Drip-irrigated and NP-fertigated high density apple trees on coarse-textured soils are already known to be susceptible to development of K-deficiency from localized soil K-depletion (Neilsen et al., 2000). Such a tendency would likely be accelerated under mulch treatments, such as black plastic, but inhibited by application of alfalfa mulch.

Treatment effects on leaf $\mathrm{Mg}$ concentration were generally opposite to those observed for leaf K. For example, trees grown with alfalfa and paper mulches which had elevated leaf $\mathrm{K}$ concentrations had depressed leaf $\mathrm{Mg}$ concentrations relative to check trees, 1995-99 (Table 4). Similar decreases in leaf $\mathrm{Mg}$ concentration were observed for trees in treatments involving black plastic (2 years) and shredded paper over GVRD-biosolids (1 year). Minimum leaf Mg concentrations were below $20 \mathrm{~g} \cdot \mathrm{kg}^{-1}$ for trees mulched with alfalfa hay. Apple trees are expected to be susceptible to $\mathrm{Mg}$ deficiency at such leaf concentrations (Shear and Faust, 1980). This implies that in the long term, mulches such as alfalfa which increase leaf $\mathrm{K}$ concentration can have detrimental effects on tree $\mathrm{Mg}$ nutrition even though beneficial effects on fruit size and yield were measurable during the first five production seasons.

There were no consistent effects of mulch treatments on leaf $\mathrm{Ca}$ concentration, with increases (shredded paper and GVRD-biosolids) or decreases (alfalfa) relative to check trees occurring no more than twice in 6 years (Table 4). Concentrations were unlikely to influence growth and were typical values observed for normally growing apple trees in the Pacific Northwest.

Micronutrients. Leaf Zn concentration was frequently affected ( 5 of 6 years) by treatment (Table 5). However, only for treatments involving the application of GVRD-biosolids were increases relative to check trees observed in more than one year. Increased leaf $\mathrm{Zn}$ concentration was observed in 1995 and 1998, both years following the application of GVRD-biosolids in the paper plus GVRD-biosolids treatment. Application of GVRD-biosolids alone increased leaf $\mathrm{Zn}$ concentrations for two successive years, but only following the second application of GVRD-biosolids in 1997. GVRD-biosolids has a high total Zn concentration (Table 1), which resulted in the co-application of $34 \mathrm{~kg} \mathrm{Zn}$ per treated hectare twice in the relevant treatments. Application of mulches without biosolids was less effective at increasing leaf $\mathrm{Zn}$ concentrations, with increases relative to check treatments observed in a single year early in the study for trees mulched with paper, alfalfa, or black plastic.

$\mathrm{Zn}$-deficiency is common on apple trees in the Pacific Northwest (Neilsen et al., 1988) with leaf Zn concentrations frequently $<14 \mathrm{mg} \cdot \mathrm{kg}^{-1}$, a concentration commonly considered a deficiency threshold for apple (Shear and Faust, 1980). It is therefore encouraging that treatments involving the application of GVRD-biosolids, excepting 1999 with shredded paper, always maintained leaf $\mathrm{Zn}$ concentration $>14 \mathrm{mg} \cdot \mathrm{kg}^{-1}$ in contrast to check treatments, which resulted in leaf $\mathrm{Zn}$ concentration $\leq 14$ $\mathrm{mg} \cdot \mathrm{kg}^{-1}, 1997-99$. The longevity of the effect from $\mathrm{Zn}$ applications with soil amendments is in doubt since leaf $\mathrm{Zn}$ concentrations declined from maximum values in the years immediately following biosolids applications.

Leaf Mn concentration was also affected by treatment in 5 of 6 years (Table 5). Over time, the most noteworthy effect was an elevation of leaf Mn concentration associated with application of GVRD-biosolids which resulted in trees in this treatment having higher leaf $\mathrm{Mn}$ than check trees in 3 years. Apparently co-application with paper with a high $\mathrm{Ca}$ content (Table 1) mitigated these Mn increases which were measured only in 1995 for the shredded paper and biosolids treatment while the shredded paper mulch resulted in low leaf Mn concentration, significantly less than check trees in 1996. High leaf Mn was occasionally observed for trees grown with alfalfa mulch (2 years), black plastic and shredded paper plus Kelowna biosolids for a single year.

Increased leaf Mnconcentration is associated with decreased soil $\mathrm{pH}$ for apple (Hoyt, 1988). Annual application of $45 \mathrm{t} \cdot \mathrm{ha}^{-1}$ of GVRD-biosolids has previously been associated with a decrease in soil $\mathrm{pH}$ after 3 years in sandy soils (Neilsen et al., 1998) and this is the likely explanation for increased leaf Mn concentrations for this treatment. However for no treatment was the increase in leaf Mn concentration close to the problem concentrations exceeding 120 $\mathrm{mg} \cdot \mathrm{kg}^{-1}$ that have been reported for 'Delicious' apple trees stunted from bark measles (Fisher et al., 1977). Since leaf Mn concentrations also exceeded the $25 \mathrm{mg} \cdot \mathrm{kg}^{-1}$ deficiency

Table 5. Average leaf nutrient Zn, Mn, and Cu of 'Spartan' apple on M.9 rootstock as affected by soil management treatments, $1994-99$.

\begin{tabular}{|c|c|c|c|c|c|c|c|c|c|c|c|c|c|c|c|c|c|c|}
\hline \multirow[b]{2}{*}{ Treatment } & \multicolumn{6}{|c|}{ Leaf $\mathrm{Zn}\left(\mathrm{mg} \cdot \mathrm{kg}^{-1} \mathrm{dw}^{2}\right)$} & \multicolumn{6}{|c|}{ Leaf Mn $\left(\mathrm{mg} \cdot \mathrm{kg}^{-1} \mathrm{dw}\right)$} & \multicolumn{6}{|c|}{ Leaf $\mathrm{Cu}\left(\mathrm{mg} \cdot \mathrm{kg}^{-1} \mathrm{dw}\right)$} \\
\hline & 1994 & 1995 & 1996 & 1997 & 1998 & 1999 & 1994 & 1995 & 1996 & 1997 & 1998 & 1999 & 1994 & 1995 & 1996 & 1997 & 1998 & 1999 \\
\hline $\begin{array}{l}\text { Check } \\
\text { (herbicide } \\
\text { strip) }\end{array}$ & $17.1 \mathrm{c}$ & $18.5 \mathrm{c}$ & $16.3 \mathrm{ab}$ & 14.0 & $12.2 \mathrm{c}$ & $12.1 \mathrm{~b}$ & $59 \mathrm{c}$ & $50 \mathrm{c}$ & $50 \mathrm{ab}$ & 45 & $36 \mathrm{~cd}$ & $32 \mathrm{bc}$ & 4.6 & $5.3 \mathrm{a}$ & $8.0 \mathrm{a}$ & $7.2 \mathrm{a}$ & $8.0 \mathrm{ab}$ & $6.2 \mathrm{~b}$ \\
\hline $\begin{array}{l}\text { GVRD- } \\
\text { biosolids }\end{array}$ & $18.4 \mathrm{c}$ & $24.1 \mathrm{bc}$ & $18.3 \mathrm{a}$ & 16.9 & $21.4 \mathrm{a}$ & $18.6 \mathrm{a}$ & $75 \mathrm{bc}$ & $103 \mathrm{a}$ & $59 \mathrm{a}$ & 46 & $55 \mathrm{a}$ & $40 \mathrm{a}$ & 4.3 & $4.5 \mathrm{ab}$ & $7.6 \mathrm{a}$ & $6.6 \mathrm{a}$ & $8.9 \mathrm{a}$ & $7.4 \mathrm{a}$ \\
\hline $\begin{array}{l}\text { Shredded } \\
\text { paper } \\
\text { mulch }\end{array}$ & $23.9 \mathrm{ab}$ & $18.3 \mathrm{c}$ & $14.9 \mathrm{~b}$ & 15.1 & $13.2 \mathrm{c}$ & $12.1 \mathrm{~b}$ & $77 \mathrm{bc}$ & $44 \mathrm{c}$ & $38 \mathrm{c}$ & 35 & $32 \mathrm{~d}$ & $28 \mathrm{c}$ & 4.3 & $3.5 \mathrm{~b}$ & $7.2 \mathrm{a}$ & $6.3 \mathrm{a}$ & $7.9 \mathrm{ab}$ & $6.6 \mathrm{ab}$ \\
\hline $\begin{array}{l}\text { Alfalfa } \\
\text { mulch }\end{array}$ & $21.4 \mathrm{bc}$ & $26.4 \mathrm{~b}$ & $13.9 \mathrm{~b}$ & 15.2 & $14.5 \mathrm{c}$ & $12.5 \mathrm{~b}$ & $83 \mathrm{~b}$ & $72 b$ & $49 \mathrm{a}-\mathrm{c}$ & 49 & $45 \mathrm{~b}$ & $35 \mathrm{ab}$ & 4.3 & $4.8 \mathrm{ab}$ & $5.2 \mathrm{~b}$ & $4.6 \mathrm{~b}$ & $5.6 \mathrm{c}$ & $4.1 \mathrm{c}$ \\
\hline $\begin{array}{c}\text { Shredded } \\
\text { paper \& } \\
\text { Kelowna } \\
\text { biosolids }\end{array}$ & $18.6 \mathrm{c}$ & $19.1 \mathrm{c}$ & $14.1 \mathrm{~b}$ & 15.8 & $14.0 \mathrm{c}$ & $13.1 \mathrm{~b}$ & $77 \mathrm{bc}$ & $68 \mathrm{~b}$ & $48 \mathrm{a}-\mathrm{c}$ & 45 & $39 b-d$ & $32 \mathrm{bc}$ & 5.1 & $3.8 \mathrm{~b}$ & $5.2 \mathrm{~b}$ & $5.7 \mathrm{ab}$ & $7.2 \mathrm{~b}$ & $4.7 \mathrm{c}$ \\
\hline $\begin{array}{l}\text { Black } \\
\text { plastic }\end{array}$ & & & & & & & & & & & & & & & & & & \\
\hline $\begin{array}{c}\text { mulch } \\
\text { Shredded } \\
\text { paper \& } \\
\text { GVRD }\end{array}$ & $26.4 \mathrm{a}$ & $21.0 \mathrm{bc}$ & $16.1 \mathrm{ab}$ & 16.7 & $13.9 \mathrm{c}$ & $13.1 \mathrm{~b}$ & $103 \mathrm{a}$ & $57 \mathrm{bc}$ & $46 \mathrm{bc}$ & 46 & $40 \mathrm{bc}$ & $32 \mathrm{bc}$ & 4.3 & $3.6 \mathrm{~b}$ & $7.8 \mathrm{a}$ & $6.2 \mathrm{a}$ & $7.1 \mathrm{~b}$ & $6.2 \mathrm{~b}$ \\
\hline $\begin{array}{l}\text { biosolids } \\
\text { Significance }\end{array}$ & $\begin{array}{c}20.2 \mathrm{bc} \\
* *\end{array}$ & $\begin{array}{l}32.2 \mathrm{a} \\
* * * *\end{array}$ & $\begin{array}{c}18.7 \mathrm{a} \\
*\end{array}$ & $\begin{array}{c}16.5 \\
\text { NS }\end{array}$ & $\begin{array}{l}18.2 \mathrm{~b} \\
* * * *\end{array}$ & $\begin{array}{c}13.1 \mathrm{~b} \\
* * * *\end{array}$ & $\begin{array}{c}72 \mathrm{bc} \\
* *\end{array}$ & $\begin{array}{l}109 \mathrm{a} \\
* * * *\end{array}$ & $\begin{array}{c}52 \mathrm{ab} \\
*\end{array}$ & $\begin{array}{l}44 \\
\text { NS }\end{array}$ & $\begin{array}{c}42 \mathrm{bc} \\
* * *\end{array}$ & $\begin{array}{l}29 \mathrm{c} \\
* *\end{array}$ & $\begin{array}{l}3.9 \\
\text { NS }\end{array}$ & $\begin{array}{l}5.7 \mathrm{a} \\
*\end{array}$ & $\begin{array}{r}7.8 \mathrm{a} \\
* * * *\end{array}$ & $\begin{array}{c}7.0 \mathrm{a} \\
*\end{array}$ & $\begin{array}{c}8.7 \mathrm{a} \\
* *\end{array}$ & $\begin{array}{r}7.2 \mathrm{a} \\
* * * *\end{array}$ \\
\hline
\end{tabular}


threshold for all treatments throughout the study, changes in $\mathrm{Mn}$ availability have, as yet, had little practical significance. Change in soil $\mathrm{pH}$ induced by mulch or amendment treatments is the chief factor affecting leaf $\mathrm{Mn}$ concentration. A decline in soil $\mathrm{pH}$, as after GVRD-biosolids application, increases leaf Mn while Mn concentration decreases after application of a high Ca paper mulch.

Leaf $\mathrm{Cu}$ concentrations were affected by soil management treatments in 5 of 6 years and the effect was generally a reduction in leaf $\mathrm{Cu}$ relative to the check treatment (Table $5)$. For example, leaf $\mathrm{Cu}$ concentration was relatively decreased for 4 years for the shredded paper plus Kelowna biosolids and alfalfa mulch treatments, for 2 years under black plastic, and for a single year under shredded paper. This either reflects a low $\mathrm{Cu}$ content of the mulch (alfalfa) or co-application of high amounts of $\mathrm{Ca}$ (shredded paper plus Kelowna biosolids) (Table 1). For the two treatments involving application of GVRD-biosolids, leaf $\mathrm{Cu}$ significantly increased relative to check trees in 1999 only, after the second application. These results imply that mulches can decrease $\mathrm{Cu}$ availability to apple trees, requiring increased vigilance in orchards where leaf $\mathrm{Cu}$ concentrations are close to deficiency values of 4 to $5 \mathrm{mg} \cdot \mathrm{kg}^{-1}$ (Shear and Faust, 1980). In contrast, two applications of $45 \mathrm{t} \cdot \mathrm{ha}^{-1}$ of high Cu GVRD-biosolids (Table 1) were required before significant increases in leaf $\mathrm{Cu}$ concentration were measured.

\section{Conclusions}

Vigor and yield of a high density, fertigated apple orchard over the first five fruiting seasons was increased by soil management treatments involving the application of biosolids, various surface mulches, or both. Yield was lowest for trees grown with the normal commercial production practice involving maintenance of a wide ( $2 \mathrm{~m}$ ) weed-free strip by multiple applications of glyphosate. Improved tree growth was not associated with improved availability of any single nutrient, as indicated by minimal and inconsistent effects of soil management treatments on leaf $\mathrm{N}$ concentration. Fertigation of $\mathrm{N}$ appeared to negate major differential effects which may have resulted from the application of mulches containing different $\mathrm{N}$ contents.
Soil management treatments did however affect nutrient availability. Leaf $\mathrm{P}, \mathrm{Zn}$, and $\mathrm{Cu}$ concentrations increased when biosolids were applied. Mulches with a high K content prevented the decline in leaf $\mathrm{K}$ concentration reported for trees grown in coarse-textured soils which are NP-fertigated. Mulches had few positive effects on leaf micronutrient nutrition and sometimes decreased leaf $\mathrm{Cu}$ concentration. Other nonnutritional factors likely contributed to improved tree performance. These include the extent to which surface mulches conserved soil moisture and reduced tree water stress in these planting systems which normally would be considered adequately irrigated when drip irrigated daily. Changes in soil properties and hence soil quality may also be critical since populations of beneficial and deleterious soil organisms were altered by these soil management treatments (Forge et al., 2003).

\section{Literature Cited}

Baxter, P. 1970. Orchard soil management trials 1. Effect of a weed-free or straw mulched strip on the growth and yield of young fruit trees. Aust. J. Exp. Agr. Animal Husbandry 10:467-473.

Boynton, D. and L.C. Anderson. 1956. Some effects of mulching, nitrogen fertilization and liming on McIntosh apple trees and soil under them. Proc. Amer. Soc. Hort. Sci. 67:26-36.

British Columbia Ministry of Agriculture and Food. 1998. Tree fruit production guide for commercial growers. Interior districts 1998-99 edition. BC Ministry of Agr., Fisheries and Food, Victoria, B.C.

Cockcroft, B. and J.M. Tisdall. 1974. Soil management of irrigated young peach trees in the Goulburn Valley, Victoria. Aust. J. Expt. Agr. Anim. Husb. 14:269-272.

Fisher, A.G., G.W. Eaton, and S.W. Porritt. 1977. Internal bark necrosis of Delicious apple in relation to soil $\mathrm{pH}$ and leaf manganese. Can. J. Plant Sci. 57:297-299.

Forge, T.A., E. Hogue, D. Neilsen, and D. Neilsen. 2003. Effects of organic mulches on soil microfauna in the root zone of apple: Implications for nutrient fluxes and functional diversity of the soil food web. Appl. Soil Ecol. 22:39-54.

Hartley, M.J., J.B. Reid, A. Rahman, and J.A. Springett. 1996. Effect of organic mulches and a residual herbicide on soil bioactivity in an apple orchard. N.Z. J. Crop Hort. Sci. 24:183-190.

Haynes, R.J. 1980. Influence of soil management practice on the orchard agro-ecosystem. AgroEcosystems 6:3-32.

Hogue, E.J. and G.H. Neilsen. 1987. Orchard floor vegetation management. Hort. Rev. 9: 377-430.

Hoyt, P.B. 1988. The relationship of internal bark necrosis in 'Delicious' apples to tree characteristics and soil properties. Commun. in Soil Sci. Plant Anal. 19:1041-1048.

International Society for Horticultural Science. 1990. Symposium on integrated fruit production. Acta Hort. 285, Wädenswil, Switzerland.

International Society for Horticultural Science. 1996. International conference on integrated fruit production. Acta Hort. 422, Cedzna, Poland.

Merwin, I.A., D.A. Rosenberger, C.A. Engle, D.L. Rist, and M. Fargione. 1995. Comparing mulches, herbicides, and cultivation as orchard groundcover management systems. HortTechnology 5:151-158.

Merwin, I.A. and W.C. Stiles. 1994. Orchard ground cover management impacts on apple tree growth and yield, and nutrient availability and uptake. J. Amer. Soc. Hort. Sci. 119:209-215.

Merwin, I.A., W.C. Stiles, and H.M. VanEs. 1994. Orchard ground cover management impacts on soil physical properties. J. Amer. Soc. Hort. Sci. 119:216-222.

Neilsen, D., P.B. Hoyt, and A.F. McKenzie. 1988. Comparison of soil tests and leaf analysis as methods of diagnosing $\mathrm{Zn}$ deficiency in British Columbia apple orchards. Plant \& Soil 105: 47-53.

Neilsen, G.H., E.J. Hogue, D. Neilsen, and B.J. Zebarth. 1998. Evaluation of organic wastes as soil amendments for cultivation of carrot and chard on irrigated sandy soils. Can. J. Soil Sci. 78:217-225.

Neilsen, G.H., D. Neilsen, and F. Peryea. 1999. Response of soil and irrigated fruit trees to fertigation or broadcast application of nitrogen, phosphorus and potassium. HortTechnology 9:393-401.

Neilsen, G.H., P. Parchomchuk, D. Neilsen, and B.J. Zebarth. 2000. Drip-fertigation of apple trees affects root distribution and development of $\mathrm{K}$ deficiency. Can. J. Soil Sci. 80:353-361.

SAS Institute. 1989. SAS/STAT user's guide. Version 6, Vol. 2. SAS Inst., Cary, N.C.

Schink, A.M.E. and S.J. Wertheim. 1992. Components and systems research for integrated fruit production. Neth. J. Agr. Sci. 40:257-268.

Shear, C.B. and M. Faust. 1980. Nutritional ranges in deciduous tree fruits and nuts. Hort. Rev. 2 : 142-163.

Shribbs, J.M. and W.A. Skroch. 1986. Influence of 12 ground cover systems on young 'Smoothee Golden Delicious' apple trees: I. Growth. J.Amer. Soc. Hort. Sci. 111:505-528.

Wittneben, U. 1986. Soils of the Okanagan and Similkameen valleys. Ministry of the environment. Tech. Rpt. 10. British Columbia Soil Survey, Rpt. 52, Victoria, B.C. 